\title{
A herança judaica em Tatiana Salem Levy e Régine Robin
}

\author{
Eurídice Figueiredo ${ }^{1}$
}

Résumé: L'héritage juif est devenu très présent dans la littérature occidentale surtout depuis les années 1970. Des écrivains comme Tatiana Salem Levy et Régine Robin n'étant pas religieuses discutent dans leurs livres la permanence de la judéité tout en révélant des conflits de génération, la fidélité à la religion ancestrale, à savoir, le devenir juif: comment chacun se place vis-à-vis du passé et du futur, comment chacun se transforme au long de l'Histoire lorsque l'on a à l'horizon un savoir et une tradition à préserver. La pluralité identitaire est un des aspects privilégiés puisque, à cause de la diaspora, les juifs ont acquis des identités multiples, tout en conservant leur héritage commun.

Mots clés: littérature du Québec ; littérature du Brésil ; judéité ; littérature comparée

Resumo: A herança judaica tornou-se muito presente na literatura ocidental sobretudo desde os anos 1970. Escritoras como Tatiana Salem Levy e Régine Robin, não sendo religiosas, discutem em seus livros a permanência da judeidade, revelando alguns conflitos de geração, a fidelidade à religião ancestral, ou seja, o devir judeu: como cada um se coloca em relação ao passado e ao futuro, como cada um se transforma ao longo da História tendo em seu horizonte um saber e uma tradição a serem preservados. A pluralidade identitária é um dos aspectos privilegiados já que, por causa da diáspora, os judeus adquiriram múltiplas identidades, conservando a herança comum.

Palavras chave: literatura do Quebec; literatura do Brasil; judeidade; literatura comparada

On sait bien que l'écriture prend toujours le sujet en défaut. Autobiographie, autofiction, autoanalyse, autobiotexte, tout ce qu'on veut. Jouer avec l'identité narrative, savoir qu'on joue avec, c'est tout (Régine Robin).

1 Eurídice Figueiredo, doutora pela UFRJ (1988), é professora associada de Literaturas Francófonas e Literatura Comparada na Universidade Federal Fluminense (UFF). Foi coordenadora do PPG em Letras, do GT da ANPOLL "Relações literárias interamericanas". Publicou Representações de etnicidade (7 Letras, 2010) Construção de identidades pós-coloniais na literatura antilhana (1998) e inúmeros artigos em obras coletivas e revistas nacionais e internacionais. Organizou, entre outros, o livro Conceitos de literatura e cultura (2005), além de números de revistas. É pesquisadora do $\mathrm{CNPq}$. 


\section{Judaísmo e Judeidade}

Na França há um crescente número de escritores que tematizam a herança judaica desde os anos 1970, dentre os quais se destacam nomes como os de Patrick Modiano, Georges Perec, Serge Doubrovsky, Régine Robin (que emigrou para o Quebec). Trata-se de escritores que eram crianças durante a ocupação ou nasceram logo depois da guerra. No Brasil, Moacyr Scliar foi, sem dúvida, o maior expoente a ter explorado em seus romances e ensaios a cultura judaica. A nova geração, representada por algumas mulheres como Tatiana Salem Levy, Adriana Armony e Cintia Moscovich, tem dado uma grande contribuição para dar maior visibilidade a esta problemática da tradição que deve ser transmitida. A pluralidade identitária é um dos aspectos privilegiados já que, em consequência da diáspora, os judeus adquiriram múltiplas identidades, preservando a herança comum, como assinala Betty B. Fuks: "O sujeito da Diáspora, à diferença de um exilado político expulso de sua própria pátria, nasceu em um país no qual ele se situa simultaneamente dentro e fora, num entre-dois cujas 'fronteiras' lhe permitem partilhar a identidade do povo da nação na qual ele existe e manter uma 'pedaço de si' sempre alhures, no espaço marginal do não-lugar” (FUKS, 2000, p. 48).

O escritor franco-tunisiano-judeu Albert Memmi criou (1962) o conceito de judeidade, que tem sido muito empregado desde então. Ele distingue três termos: a judeidade (judéité) é o fato e a maneira de ser judeu; o judaísmo (judaïsme) é o conjunto de doutrinas e instituições judaicas; a judaicidade (judaïcité) é o conjunto de pessoas judias (MEMMI, 1962, p. 29). Para ele, há sempre algo de místico em toda memória coletiva, mas na tradição judaica isto é particularmente marcado por sua antiguidade e pela obstinação e tenacidade com que o povo judeu preserva e dá continuidade a um conjunto de hábitos que definem seu pertencimento. Segundo ele, os aspectos subjetivos da judeidade não são muito pesados porque o indivíduo pode preferir ficar à margem da vida da comunidade. No entanto, a comunidade (a judaicidade) se impõe a ele como "fatos exteriores e objetivos", que ele pode confirmar ou negar. Com isso ele conclui assim sua definição de judeidade:

A judeidade é, inicialmente, um conjunto de fatos, condutas, instituições, que encontro em mim, mas, sobretudo, fora de mim, ao longo de minha vida. Antes de ser o objeto de minha escolha, de uma decisão de minha vontade, são, em suma, fatos sociais. Sua confirmação ou seu questionamento, por mais importantes que sejam, são procedimentos suplementares (MEMMI, 1962, p. 300-301).

A judeidade remete à trama de significações tradicionais, culturais, históricas, que forma o indivíduo e lhe confere sua real fisionomia (MEMMI, 1962, p. 303). Assim, uma tradição cultural é a "soma de maneiras de viver, de atitudes mentais, de riquezas confusas"; tudo isso se funde num amálgama que é digerido e incorporado de tal maneira que ele constitui uma maneira de ser coletivo, e que é transmitido pela herança (MEMMI, 1962, p. 306).

A judeidade se distingue do judaísmo, que se refere à religião; a judeidade tem mais a ver com as práticas culturais herdadas dos ancestrais, o respeito a alguns valores, tradições e instituições - como as festas religiosas - que até fazem parte da religião, mas que não são expressão de uma verdadeira religiosidade. Como no mundo cristão, em que se comemoram o Natal e a Páscoa, sem que se dê a eles um cunho religioso, alguns judeus festejam o ano novo comendo o pão ázimo e a maçã com mel, sem lhe conferir um aspecto transcendente. Apesar de a laicidade ser muito difundida entre os judeus, a religião nunca está totalmente descartada, como ela pode estar entre os cristãos. A narradora de $A$ chave da casa, de Tatiana Salem Levy, considera que faltava verdade nas festas que celebravam 
em casa, que eles eram judeus uma vez por ano, mas a mãe, sempre sensata, lhe diz: "Não era a religião o que nos importava, mas a tradição. Não queríamos simplesmente jogar na lata do lixo aquilo que nossos antepassados se esforçaram para guardar. O importante era manter a simbologia" (LEVY, 2009, p. 130). Comentando a importância da memória na tradição judaica, Betty Fuks afirma:

Em cada época, em cada geração, o leitor interpreta subjetivamente aquilo que lhe é transmitido, preservando as estruturas tradicionais da transmissão e assegurandolhes continuidade. Não seria descabido lembrar também que o modo de se fazer a narrativa, o ritmo, o timbre, o som das melodias e os movimentos do corpo são também uma linguagem, plena de sentidos, sem que necessariamente chegue-se a conhecer sua significação (FUKS, 2000, p. 135).

Escritoras como Tatiana Salem Levy e Régine Robin, que não são religiosas, discutem em seus livros a permanência da herança judaica, revelando alguns conflitos de geração, a maior ou menor fidelidade à religião, ou seja, o devir judeu: como cada um se coloca em relação ao passado e ao futuro, como cada um se transforma ao longo da História tendo em seu horizonte um saber e uma tradição herdados.

Derrida, lendo Yerushalmi, afirma que o judaísmo é terminável, a judeidade é interminável. "Ela pode sobreviver ao judaísmo. Pode sobreviver a ele como herança, isto é, de todo modo, não sem arquivo, mesmo se este arquivo ficar sem suporte e sem atualidade. Para Yerushalmi, há uma essência determinante e irredutível da judeidade: ela já está dada e não espera o futuro" (DERRIDA, 2001, p. 93. Grifo do autor). Paradoxalmente, ela não espera o futuro porque ela é a própria crença no futuro, ela é o traço que une ao futuro. "O ser-judeu e o ser-aberto-ao-futuro seria a mesma coisa, a mesma única coisa, a mesma coisa como unicidade - e não poderíamos dissociar uma da outra. Ser aberto ao futuro seria ser judeu". Um outro traço seria a abertura "à historicidade e à obrigação da memória, ou melhor, à obrigação do arquivo" (DERRIDA, 2001, p. 96. Grifos do autor). A experiência da promessa (o futuro) e a injunção da memória (o passado) se unem, uma se fundamenta na outra "porque houve um evento arquivado" (DERRIDA, 2001, p. 97) que fundou o judaísmo.

Assim, a injunção da memória é tematizada por ambas as escritoras. Régine Robin tematiza a memória da Shoah, o trauma dos ancestrais mortos nos campos de concentração, o que provoca uma grande melancolia em seus textos. Já Tatiana Salem Levy, da nova geração, neta de judeus que emigraram para o Brasil, trata da tradição judaica sob um outro viés, o que não exclui, porém, uma dor que pesa sobre seus ombros.

\section{Régine Robin: autoficção, bioficção, ciberficção².}

Régine Robin, nascida em Paris em 1939, é uma das criadoras pós-modernas de autoficção. Filha de judeus poloneses, foi professora de Sociologia de Paris X, emigrou para o Canadá (1977), tornando-se professora da UQAM (Université du Québec à Montréal) em 1982. Escreveu tanto textos ensaísticos como Le Golem de l'écriture. De l'autofiction au Cybersoi (1997), quanto obras de ficção, dentre outros o romance La québécoite (1983) e L'immense fatigue des pierres (1996), livro de narrativas curtas (contos ou novelas), que

2 A partir da noção de romance (ficção) autobiográfico, que é a escrita ficcional de sua própria vida, surgiram os termos de autoficção (para designar a ficcionalização de si mesmo), bioficção (para designar a ficcionalização de sua vida) e ciberficção (para designar os biografemas disponíveis na Intenet). 


\section{Conexão Letras}

ela chama de bioficções. Numa busca sobre a "identidade pluralizada pelos fantasmas de auto-engendramento" (ROBIN, 1997, p. 16), ela constata que nos dias de hoje as fronteiras "entre o escritor, o narrador e os personagens, entre o artista e sua instalação" estão abolidas, ou melhor, as fronteiras são porosas e permitem a passagem (ROBIN, 1997, p. 17). A autoficção toma a forma disseminada de Proteu, que é o desejo de "ocupar todos os lugares", desempenhando todos os papéis: "Representar todos os outros que estão em mim, me transformar em outro, dar livre curso a todo processo de virar outro, virar seu próprio ser de ficção ou, mais exatamente, esforçar-se para experimentar no texto a ficção da identidade; tantas tentações fortes, quase a nosso alcance e que saem atualmente do domínio da ficção" (ROBIN, 1997, p. 16).

O romancista canadense de origem haitiana Dany Laferrière, no livro de entrevistas $J^{\prime}$ écris comme je vis, afirma que em literatura não pode haver confissão, pois a sinceridade é o primeiro artifício, e que "para colocar em cena sessenta por cento de sinceridade, é preciso quarenta por cento de artifícios. A verdade tem necessidade de ser verossímil (LAFERRIÈRE, 2000, p. 119), no que ele concorda com Paul Valéry, que já afirmava que "em literatura o verdadeiro não é concebível" e que qualquer tipo de "confidência visa à glória, ao escândalo, à desculpa, à propaganda” (VALÉRY, 1957, p. 570-571).

Régine Robin encena suas múltiplas identidades nas sete bioficções de L’immense fatigue des pierres, nas quais os nomes são intercambiáveis, vão, voltam, se transformam. Os temas obsessivos que permeiam a obra são as travessias de línguas, culturas, histórias, geografias, nomes próprios, evocando desde a Shoah até a criação de biografias na Internet. A protagonista em todas as bioficções é uma escritora (ou escritor) de pouco mais de 60 anos, que fuma cigarros Saint Moritz Menthol, adora beber uísque nos cafés, vive em/entre Paris, Montreal e Nova York. Ao criar a personagem da escritora, que se desdobra em vários papéis, Robin encontrou a estratégia narrativa para poder se infiltrar em todos os lugares, viajar e conhecer todo tipo de pessoa. Os seres que habitam suas cidades imaginárias podem ser muito semelhantes aos de suas verdadeiras cidades como também podem ser diferentes. Segundo $\mathrm{Ph}$. Vilain, a particularidade da imaginação autobiográfica reside em sua capacidade de desdobramento narcísico que permite ao sujeito inventar para si um duplo, ideal ou não, e tornar possível uma forma de autoficcionalização (VILAIN, 2005, p. 119).

A protagonista vive uma judeidade cheia de ambiguidades, traumas, recusas, fantasmas. A experiência traumatizante da guerra, durante a qual a protagonista se escondeu, usou ou não a estrela, perdeu familiares nos campos de concentração principalmente de Treblinka e de Auschwitz — , está presente de modo obsedante no tramado de suas fabulações de si.

Na primeira novela, que dá título à obra, mãe e filha se alternam no papel de narradoras. Todas duas deixam Paris: a mãe mora em Nova York, enquanto a filha mora em Jerusalém. Há uma incomunicabilidade entre elas, que pouco se veem, e quando o fazem, só trocam amenidades, nenhuma consegue realmente conversar com a outra. De modo significativo, elas se encontram em aeroportos, estes "não-lugares", na expressão de Marc Augé, para o qual o "não-lugar" designa duas realidades complementares porém distintas: de um lado, seria o espaço constituído para certos fins (transporte, comércio, trânsito), e de outro, a relação que os indivíduos entretêm com estes espaços. Ao contrário do lugar antropológico, que cria um social orgânico, o não-lugar cria uma contratualidade solitária (AUGÉ,1992, p. 118-119). As duas personagens são solitárias e mantêm uma relação problemática com a herança judaica, que constitui fator axial e fonte de conflito. A mãe, Nancy Nibor (anagrama de Robin), acusa mentalmente a filha de excesso de judaísmo, porém 
sabe que não lhe dirá nada ao encontrá-la. A filha, que foi morar em Israel para contrariar a mãe e, ao mesmo tempo, para buscar e/ou afirmar seu judaísmo, só encontrou fragmentos de identidade, estilhaços de sentido, e sobretudo, nenhuma cumplicidade com a memória dos ancestrais. Ela exprime uma grande frustração e um sentimento de incompletude, de inadequação ao papel que ela construíra para si, mas sabe que também não falará sobre isto quando encontrar a mãe, ou seja, trata-se de um assunto tabu, interdito, porque é desde sempre causa de sofrimento. No final, elas evocam um projeto de ir morar em Montreal, uma cidade que é um terreno neutro, na qual elas se sentiriam bem justamente por não ser a cidade natal de nenhuma delas.

Em "Le dibbouk inconnu", o alter ego da narradora é Michel Himmelfarb, que recebe de seu editor a encomenda de um livro sobre os duplos, os desdobramentos de personalidade, o que a própria Robin fez, de certa forma, em Le Golem de l'écriture. Entretanto, mais do que simplesmente teorizar sobre a questão, ele vive os desdobramentos em sua vida, real e virtual. Após percorrer os campos de concentração da Polônia, os museus do Holocausto em Jerusalém e Washington, após ler livros e ver filmes que tratam da questão, Michel cria ciberficções, refazendo biografias das vítimas da Shoah na Internet. Um dos seus duplos é Rivka, sua irmãzinha, que morreu aos 3 anos em Treblinka, e que ressuscita em suas mãos, fazendo carreira brilhante de artista de teatro em Paris. Um outro é David Morgensztern, nascido na mesma cidade da Polônia em que ele nascera, Kaluszyn, o qual teria sido enviado a Treblinka em 1942, conforme ele vira numa ficha no museu de Washington. Contudo, um dia, ele recebe um telefonema de alguém que afirma ser o próprio David Morgensztern, que teria conseguido escapar. Em pânico, ele perde seus parâmetros de realidade e ficção. Olhando-se no espelho, pensa estar enlouquecendo, se vê como sua irmã Rivka, lembra-se da velha lenda hassídica segundo a qual cada judeu morto na Shoah viria habitar a alma de um sobrevivente. Ele seria habitado pelo dibbouk, a alma de David, que talvez lhe tenha inspirado toda sua vida, sua carreira, sua ida aos museus, sua busca em entender os duplos. Segundo Simon Harel, Régine Robin reivindica em L'immense fatigue des pierres a imagem da web como confluência dos lugares de memória. Este tropo tecnológico permite dar vida nova à memória, assegurar-lhe uma certa perenidade; assim, a web é uma arquitetura tecnológica móvel que permite que os desaparecidos reapareçam, dando sentido à trama frouxa de nossas existências (HAREL, 2006, p. 300).

Em "L'agenda", a personagem da filha tenta escrever a biografia da mãe morta a partir dos fragmentos deixados por ela em suas agendas, únicos manuscritos conservados pela filha, que havia doado todo o resto às bibliotecas. Ele faz exercícios de estilo, passando pelo jornal íntimo até chegar à forma poética, que melhor dá conta do caráter lacunar e parcelar que têm estes biografemas.

"Gratok. Langue de vie et langue de mort" começa com a evocação da Paris da Ocupação, em 1944, quando a protagonista tinha menos de 6 anos (por isto não tinha de usar a estrela) e se escondia com sua mãe e outros judeus numa garagem abandonada na rua Vilin. Robin presta uma homenagem a dois escritores judeus: Serge Doubrovsky, que ficou escondido na Paris ocupada, e a Georges Perec, que morava no número 24 da rua Vilin, como ele diz no livro L'infra-ordinaire (1989, p. 18) enquanto a família materna morava no número 1.0 pai de Perec morreu na guerra (1940) e a mãe enviou o pequeno Georges para Villard-de-Lans num trem da Cruz Vermelha. Ele ficou lá, com a família paterna, até o fim da guerra, quando voltou para Paris, tendo sido adotado pela irmã do pai. A mãe de Perec foi deportada e morreu no campo de concentração de Auschwitz em 1943. Para dar maior peso de realidade ao fato, consta também no livro parte do mapa de ruas de Paris 
em que se situa a rua Vilin (a meio caminho das estações de metrô de Ménilmontant e de Pyrénées). Na garagem, a menina não podia fazer barulho, tinha de aprender a falar para dentro, a tossir para dentro. $\mathrm{Na}$ rua, não podia falar com outras crianças pois seu forte sotaque da Europa Central em francês a teria denunciado. Um dia a mãe consegue alguém para tomar conta dela, uma francesa chamada Juliette, em cuja casa as pessoas cantam, riem, são felizes. Com ela vai aprender a falar francês como as outras crianças. A partir daquele momento, o francês passará a ser associado à alegria, à festa, à música, enquanto o iídiche falado na garagem se tornará uma língua de morte, até porque depois do fim da guerra a menina foi descobrindo muito mais mortes ainda, agora já associadas aos campos de concentração, ao cheiro de gás. Seu amor pelo francês e sua recusa do mundo representado pelo iídiche parecem uma traição a toda ideia de identidade judaica, mas o que a narradora demonstra é que sua identidade encontra-se no entre-dois: ela frequenta dois mundos, o dos que usam a estrela, se escondem e falami iídiche e dos que falam francês, se divertem e cantam, ou seja, um mundo associado à morte e um mundo associado à vida. Ela pertencia aos dois mundos, ela estava no entre-dois. A narrativa faz um corte temporal e a protagonista reaparece, 50 anos depois (portanto em 1994). Tradutora do í́diche ao francês, ela atribui as suas dificuldades, o seu sofrimento, à memória da morte associada a esta língua, à dificuldade de fazer o luto dos episódios traumáticos do passado.Traduzir do iídiche era passar da língua dos mortos (e da morte) ao mundo dos vivos (e da vida), traduzir era, para ela, uma verdadeira descida aos infernos. Ela decide mudar de profissão e tornarse escritora, tentar fazer soar o iídiche em francês, imitando sua prosódia, seu ritmo, sua respiração. Para poder realizar um trabalho de criação literária, tenta rememorar a menina que foi, a língua que ela poderia ter falado com Gratok, seu ursinho de pelúcia, em suma, uma linguagem poética. De alguma maneira ela quer reencontrar a língua inventada para falar com Gratok, uma língua que lhe permitia dizer tudo (ROBIN, 1996, p. 80-81).

Em "Mère perdue sur le World Wide Web", o protagonista encontra uma referência ao nome de sua mãe, Rivka Himmelfarb, em um livro de memórias de um sindicalista americano e descobre que, ao contrário do que pensava, ela não morrera no campo de concentração, mas tinha conseguido sobreviver, emigrara para os Estados Unidos e em seguida para Montreal. Ele deixa Paris e vai ao seu encalço em Montreal, onde descobre seus vestígios, numa investigação quase policial: seus endereços, uma cirurgia em 1968 no Jewish Hospital, seu dossiê médico, os livros emprestados na Jewish Library entre 1975 e 1977, a existência de um marido. Através da Internet, consegue mais informações, inclusive que o marido, Haïm Morgenstern, está hospitalizado. No entanto, ao visitá-lo, tem uma decepção ou, quem sabe, um alívio, pois como o ancião sofre do mal de Alzheimer, é incapaz de qualquer conversa coerente. O protagonista se pergunta então como se pode fazer o luto duas vezes, que é o que efetivamente se dá com ele, na medida em que, tal como um espectro, a mãe voltara a provocar novas emoções ligadas à sua perda.

Em "Journal de déglingue entre le Select et Compuserve", a protagonista retoma alguns fragmentos de outras narrativas: de "L'agenda", a referência ao seu estudo sobre Kafka, de "L'immense fatigue des pierres", a notícia que sua filha quer deixar Jerusalém para ir morar não se sabe onde, Nova York, Paris, Montreal. Em um dos fragmentos há um emaranhado de identidades: sentada no Select, em Paris, ela se faz passar por Emilia Morgan diante de Pamela Wilkinson e vice-versa, ficando com os trabalhos de Pamela em que ela mistura fotos, desenhos, colagens e textos. No entanto, ao ler algumas citações, ela se depara com seus próprios textos, escritos em um agenda que ela perdera em Nova York. Um outro encontro no Select coloca novas identidades em tela: ao ser indagada se ela não 
é Tartampionne, responde que se chama Martha Himmerlfarb mas diz conhecer Régine Robin. Na verdade todas elas são variantes da protagonista. "Eu sou Pamela Wilkinson, ou Emilia Morgan, ou Nancy Nibor, ou Martha Himmelfarb, ou os avatares da personagem quando participa de fóruns de discussão na Compuserve ou na Internet; talvez seja a filha da narradora, ou até mesmo Régine Robin (ROBIN, 1996, p. 130).

A protagonista possui um comércio em Montreal, "Biographie sur mesure", no qual ela vende biografias para quem quiser. Ao fazer isto, ela percebe que as pessoas não querem que ela escreva a verdade, preferindo a narrativa de suas vidas imaginadas. Assim, ela passa a fabricar passados falsos, fantasmas que passam ao ato, ou seja, autoficções (ROBIN, 1996, p. 126-127). Ela reconhece que o que transfigura, dá alma e estilo às biografias, são os fantasmas, os sonhos, as falsas lembranças. Para isto, ela não hesita em plagiar os clássicos, copiando citações de Flaubert, Stendhal ou Balzac. Os clientes, pessoas que viveram vidas ordinárias, que fizeram más escolhas, não resistem ao encanto de suas vidas metamorfoseadas. No fundo, ela dava nova chance aos infelizes permitindo-lhes "viver" uma existência mais bem realizada através da escrita (ROBIN, 1996, p. 129).

Na última narrativa, "Manhattan Bistro", a protagonista imagina como teria sido a vida dos 51 parentes dela, que morreram durante a Shoah, caso eles tivessem emigrado para os Estados Unidos antes da guerra: as duas famílias, os Ajzersztejn e os Segalik teriam chegado por volta de 1908 por Ellis Island e teriam tido uma outra vida (ROBIN, 1996, p. 146). Assim, ela, Rivka Ajzersztejn, teria nascido em 10 de dezembro de 1939 em Nova York (e não em Paris). Seria uma americana e, em vez de Régine Robin, seu nome teria se transformado em Rebecca Ajerstein (pronunciado Ajerstin). Através desta biografia imaginária, ela devolve a vida a todos estes familiares mortos, ela tenta devolver-lhes um arremedo de história (ROBIN, 1996, p. 149). Como esta ressurreição imaginária não basta, ela escreve os 51 nomes, em forma de poema da morte/dos mortos, dando-lhes, finalmente, um lugar, uma placa com nome e sobrenome. A homenagem de Régine Robin é permeada por um nominalismo que pretende dar realidade aos membros de sua família mortos nos campos de concentração. Um procedimento semelhante acontece na instalação de Christian Boltanski no Musée d'Art et d'Histoire du Judaïsme em Paris, em que ele coloca placas com os nomes de todas as pessoas que moravam em 1939 naquele prédio, o Hôtel de Saint-Aignan, e que foram deportadas.

A memória da morte e dos mortos conduz ao silêncio, à impossibilidade de dizer, à representação dos corpos abjetos, chamados em Auschwitz de figuren (bonecos, fantoches), schmattes (trapos, farrapos) ou stück (troço, treco). Assim ela faz o luto, um luto impossível. É como uma pequena cripta dentro de si, na qual se conserve, bem quentes, bem vivos, um a um, todos os seus mortos - engolidos, colocados em conserva (ROBIN, 1996, p. 169). Diante das dificuldades de resgatar o impossível, através de listas de nomes, litanias genealógicas (à maneira de Georges Perec), histórias e datas, numa estética de relíquias, pedaços, restos, lembranças, a narrativa termina com os desenhos de 51 estelas funerárias vazias, brancas, sem nenhuma inscrição.

Segundo Simon Harel, a leitura de L'immense fatigue des pierres provoca o sentimento de uma imensa solidão, sobre um fundo de banalidade tecno-cybernética que reúne protagonistas desocupados em busca de seus duplos. Mas a reflexão de Régine Robin não se reduz à encenação de uma quinquilharia tecno-cybernética. De modo ambivalente, ela nos diz que o prêt-à-porter multimidiático é o signo de uma profunda impostura embora ela não esconda uma fascinação secreta por estes jogos baseados em representações de nosso mundo hipermoderno (HAREL, 2006, p. 301). 
L'immense fatigue des pierres tem muitos elementos em comum com a persona virtual que Régine Robin mantém no seu site, com suas duas facetas representadas por dois caminhos possíveis (dois links): um, que leva ao percurso universitário, e outro, nomeado Rivka A., que conduz aos seus fragmentos de ciberficção. Assim, o nome Rivka, que aparece com frequência nas narrativas, revela-se no site como seu nome original. Pode-se ter, em estilos diferentes (dependendo do caminho que se tomar), a informação que seu sobrenome de solteira é Aizertin, seu nom de plume é Robin (de seu primeiro marido) e seu sobrenome atual é Maire (de seu segundo marido). A apresentação inicial do caminho ficcional de Rivka A. consiste em um texto que explica que o site terá 5 rubricas, cada uma delas com 52 fragmentos (o número 52 corresponde ao número de semanas por ano), com exceção da rubrica do ônibus 91, que contará com 30 fragmentos, perfazendo um total de 238 fragmentos. Sendo um site interativo, o leitor é convidado a tornar-se um co-autor, fazendo as combinações que quiser, de maneira a formar colagens e narrativas. Como ela afirma, o leitor pode conservar os vestígios de seu itinerário, bifurcando, voltando, clicando em outros links, vagando em um universo labiríntico próximo das ficções de Borges (ROBIN, 1997, p. 280).

As cinco rubricas são as seguintes : 1. boîtes de vie, fragments (no fragmento "Rivka" ela explica que em sua casa ela era chamada de Rivkale, diminutivo de Rivka em iídiche, mas na escola francesa ela sempre foi Régine); 2. bistrots; 3. rue: poétique de la ville; 4. envois, que são citações de seus autores prediletos ou então pequenos textos escritos em cartões postais (enviados, recebidos ou comprados em brechós); 5. autobus 91, que segue o itinerário do ônibus que vai da Estação Montparnasse à Bastilha, em Paris: ela descerá do ônibus em cada uma das 30 paradas, tirará uma foto, escreverá um fragmento e tomará o ônibus seguinte. Este tipo de exercício, segundo ela, é inspirado pela experimentação do grupo OULIPO (Jacques Jouet e Georges Perec). Por outro lado, o leitor se move em um espaço multidimensional que o faz passar de um fragmento a outro, sem nenhuma ordem pré-estabelecida (ROBIN, 1997, p. 279).

Ao percorrer a primeira rubrica, boîtes de vie, fragments, pode-se perceber que há, de um lado, fragmentos leves, que falam da via corrente, sem evocar o trauma da herança judaica, mas há também outros, como "Memorial invisible", que retoma a questão da Shoah, com o mesmo sentimento de melancolia e luto que aparece nas narrativas de L'immense fatigue des pierres. Ela fala de um projeto de Memorial para Birkenau, feito nos anos 50 por dois arquitetos, no qual os visitantes não pisariam no solo em que se deu a morte das vítimas e só veriam de longe, por uma fresta, os locais, com o intuito de evitar a banalização e a estetização da morte. Seria a invisibilidade que daria visibilidade, nenhuma ilusão de reconstituição, nenhum tráfico da memória.

O que se depreende destes biografemas fragmentados e embaralhados é uma grande melancolia, resultado do trauma das perdas. Doubrovsky explica que, diferentemente da autobiografia ou do romance autobiográfico, que se referem ao passado de quem escreve, a autoficção é a escrita do presente. Além disto, ela engaja diretamente o leitor, como se o autor quisesse compartilhar com ele suas obsessões históricas. Tanto no caso de Doubrovsky quanto no de Régine Robin e de tantos outros escritores judeus, trata-se de um "traumatismo insuperável" (Apud VILAIN, 2005, p. 187), a Shoah, a perda de familiares nos campos de concentração, a experiência durante a ocupação de Paris pelos nazistas. A outra obsessão dos dois escritores é a América, a ruptura que significou para ambos a emigração. Doubrovsky, indo para os Estados Unidos, teve de se separar de sua mãe, que permaneceu na França, enquanto Robin, ao partir para Montreal, deixou sua filha em Paris. 
Estas fatias de vida são repisadas até a exaustão, num emaranhado labiríntico bem característico da obsessão, como se fosse um eterno presente e não um passado bem terminado. A autoficção de Robin (como a de Doubrovsky) restitui fragmentos de memória e suscita no leitor uma inquietante estranheza diante destes vestígios do horror.

\section{Tatiana Salem Levy}

Apesar da diferença de 40 anos que separa as duas escritoras, ambas carregam a mesma tradição, ambas tematizam migrações, diásporas, identidades plurais, judeidade e judaísmo. Ao narrar a sua história autoficcional, a narradora de $A$ chave da casa, de Tatiana Salem Levy, conta, pelo menos parcialmente, a biografia de seus pais e de seu avô. Nascida em Portugal em 1979, onde seus pais estavam exilados durante a ditadura militar, ela aponta para as coincidências de sua história familiar. No passado remoto, sua família de judeus sefarditas vivia em Portugal, de onde foi expulsa, indo para a Turquia. $\mathrm{O}$ avô decidiu vir para o Brasil e os pais tiveram de se refugiar em Portugal para fugir da prisão. Com isto, eles fecharam um círculo, que a protagonista vai refazer ao longo do romance. É este peso da herança familiar que ela deve contar a fim de se curar desta crise de identidade. "Nasci no exílio: e por isso sou assim: sem pátria, sem nome. Por isso sou sólida, áspera, bruta. Nasci longe de mim, fora da minha terra - mas, afinal, quem sou eu? Que terra é a minha?” (LEVY, 2009, p. 25).

São muitas as viagens protagonizadas pela família de Tatiana Salem Levy: a do avô, a dos pais e a dela, que vai visitar a Turquia e Portugal. As narrativas vão se alternar, criando paralelismos entre elas. $\mathrm{O}$ avô deixa a Turquia devido à impossibilidade de se casar com Rosa, a filha do patrão, por quem se apaixonara. A viagem de navio, em terceira classe, para uma terra desconhecida, sozinho e amargurado pela perda de seu sonho amoroso, é triste. Além do mais, as imagens negativas que ele tinha sobre o Brasil não podiam tranquilizá-lo. "Ainda por cima, tinha ouvido falar que no Brasil havia uma quantidade enorme de ratos, baratas, animais selvagens espalhados pela rua, lixo por tudo quanto é canto, um calor irrespirável” (LEVY, 2009, p. 35). Pouco tempo depois de sua chegada, a irmã gêmea lhe revela numa carta que Rosa se suicidara, o que o coloca numa tremenda prostração. Fica um mês na cama, "seu coração estava em destroços, esfarelado como um vaso de vidro que tomba no chão" (LEVY, 2009, p. 67). Algum tempo depois, porém, conhece Hilda, com quem se casa e reconstrói sua vida. A partir daí, como a maioria dos imigrantes, prefere deixar o passado para trás. A memória será obra de filhos e netos, mais do que dos imigrantes. "Imigração, Turquia, guerra e dificuldade eram palavras banidas do vocabulário da casa. Que ninguém falasse do sofrimento nem das arduidades que ele tinha vivido antes do casamento. Afinal, o importante era que agora estavam bem, com saúde, trabalho e harmonia. O resto era passado, e o passado deve ser silenciado, adormecido entre os fios da memória" (LEVY, 2009, p. 111).

Amor, doença e herança estão intimamente ligados. O romance começa com a imagem da narradora protagonista escrevendo de mãos atadas; diz que nasceu velha, que carrega o peso de uma herança, de um nós, que se imiscui quando ela diz eu. Aliás, ela sente a presença de outros nela. "Às vezes sinto que é alguém que nunca conheci, mas que fala através de mim, do meu corpo. Como se meu corpo não fosse apenas meu, e a cada momento eu percebesse essa multiplicidade, a existência de outras pessoas me acompanhando" (LEVY, 2009, p. 12). Esta identidade plural manifesta-se de maneiras variadas. 
O avô transmite-lhe uma herança, a de buscar o passado que ele deixara para trás na Turquia. Incumbe-lhe agora recuperar a memória da família, explicar as lacunas que ficaram de um passado de ruptura, de partida, de exílio. Incumbe-lhe fazer o que o avô não fez, ou não teve coragem ou condições de fazer, voltar à casa da família que ele abandonara na Turquia. Ele foi o primeiro a vir para o Brasil, depois seu irmão mais novo veio se juntar a ele. O irmão mais velho ficou em Esmirna, enquanto a irmã gêmea morreu de tuberculose, no momento em que preparava seu casamento. Esta morte, ocorrida cinco anos depois de sua chegada no Brasil, o entristeceu muito porque os gêmeos eram muito ligados. A mãe acabaria se mudando para o Brasil muitos anos mais tarde, já viúva.

Há uma encenação de diálogo entre mãe e filha sobre a herança judaica: se a filha considera que a memória está associada ao medo, ao fardo que ela tem de carregar, a mãe afirma que lhe cabe agora falar dos silêncios, daquilo que foi rasurado. Como os pais, comunistas, não praticavam a religião, o judaísmo só continua como tradição, nas festas, na alimentação, ou seja, em forma mais propriamente de judeidade do que de judaísmo. Como (re)viver uma herança que não foi integralmente transmitida? Seria superficial, supérfluo? O abismo cavado pela viagem do avô e sua atitude de esquecimento (rejeição?) em relação ao passado mostra-se mais agudamente no momento em que a protagonista encontra os parentes na Turquia: não falando o ladino (língua falada pelos judeus sefarditas) nem o turco, ela só consegue se comunicar com o jovem Raphael, que fala inglês. A atitude da família é quase de acusação: como o avô não transmitiu a língua e, junto com ela, as tradições judaicas da família? O avô queria o esquecimento, mas os judeus nunca esquecem, eles não podem esquecer. "Um verdadeiro judeu não esquece o passado" (LEVY, 2009, p. 159), diz o ancestral; ela pensa (um pouco irônica) que talvez seu avô não fosse um verdadeiro judeu, já que ele preferiu esquecer o passado e não ensinou o ladino a seus filhos.

No romance, o tema da herança como fardo está associado ao tema da doença: ela escreve para se livrar do medo do passado, ou seja, a escrita é uma forma de terapia. Este topos da imobilidade, da podridão, da sujeira, percorre o romance. A primeira causa de sua paralisia enunciada estaria na experiência da morte de sua mãe. "Depois que conheci a morte e ela me encarou com seus olhos de pedra. Foi a morte (a sua) que me tirou, um a um, os movimentos do corpo. Que me deixou paralisada nessa cama fétida de onde hoje não consigo sair" (LEVY, 2009, p. 62). Em outro momento a narradora afirma que o amor excessivo foi o motivo de sua paralisia. "Fui perdendo a mobilidade depois que o conheci. Depois que o amei: depois que conheci a loucura através do amor (excedido) que me tirou, um a um, os movimentos do corpo" (LEVY, 2009, p. 133).

A pessoa que a ajuda a sair da clausura, do "casulo pétreo" (LEVY, 2009, p. 12), do "encarceramento" (LEVY, 2009, p. 18) que a imobiliza, é a mãe, que aparece desde o segundo capítulo em forma de voz entre colchetes, sem que se desvele de imediato de quem é a voz. A figura protetora da mãe desempenha papel importante na recuperação da protagonista, é seu o apelo para que ela continue viva, que reconheça o lugar e a presença dos mortos na consciência e na lembrança dos vivos. A relação mãe-filha aqui é muito forte, sem os mesmos conflitos que aparecem no livro de Régine Robin.

A viagem da protagonista para a Turquia suscita questões identitárias desde a chegada. Ela começa a reivindicar sua herança turca, o que lhe proporciona identidades plurais: judia, brasileira, portuguesa e turca. Ao inserir palavras e frases tanto em turco quanto em ladino e inglês em seu texto, a autora embaralha suas identidades e desterritorializa o português, penetrado por outras línguas. Neste sentido, o projeto literário de Salem Levy aproxima-se do de Régine Robin, que também desterritorializa o francês pela intrusão do iídiche. 
Uma cena central no romance $A$ chave da casa é a do banho turco, em que ela é lavada intensamente e mergulha num mundo outro, reconhece sua alteridade, ali é ela a estrangeira. Ela imagina histórias de vida para as mulheres muçulmanas que estão ali tomando banho e, ao mesmo tempo, conta sua história de vida para Sihem, a moça que a lava e a massageia. Quando descobre que ela é de ascendência turca, que está/é tensa devido ao peso de sua herança, que carrega nas costas, Sihem capricha na massagem "na tentativa de me desvencilhar do passado. Sentia que ela não estava apenas distendendo meus músculos, mas também lutando contra tudo o que eu acabara de contar" (LEVY, 2009, p. 99).

Depois de Istambul ela vai para Esmirna, onde moram os parentes. Passeando na cidade, ela busca imaginar a cidade que foi de seu avô, as ruas que ele percorrera, descrevendo uma cartografia em que se entrecruzam o seu presente vivido e o passado do avô, imaginado por ela. Esmirna, diferentemente de Istambul, que ela visita como turista, é o ponto de partida do avô e seu ponto de chegada. O primo Raphael lhe revela que a casa na qual o avô havia morado não existe mais, o que mostra a inutilidade da viagem: já não há mais porta para ser aberta com a chave do avô. Acaba sua busca memorial.

Tatiana Salem Levy cria uma narradora não confiável, que desestabiliza as categorias narrativas tradicionais, explicita o caráter metaficcional da história, o que deixa o leitor (que porventura acredita numa "verdade" do texto) desconfiado. Há duas versões para a história de seu nascimento e uma contradiz a outra. A primeira, da narradora, é negativa. Já a voz entre colchetes da mãe afirma que, ao contrário do cenário de tristeza e dor, a vida no exílio foi prazerosa, tranquila, e que o nascimento dela foi desejado e fácil. Também na história do avô há uma discussão entre a narradora e a voz da mãe, que busca enfatizar o lado alegre, positivo, da aventura do avô, que construiu sua vida no Brasil e foi muito feliz com Hilda. Ela usa também oximoros como este: "É a casa onde passei toda a minha vida, a casa onde nunca estive" (LEVY, 2009, p. 145). Pesadelo de estar trancada numa casa, de não ter a chave.

O caráter autoficcional fica por conta de alguns elementos comuns entre a protagonista e a escritora, que realmente é de ascendência turca, nasceu em Portugal durante a ditadura militar. Apesar de não ser uma autoficção no sentido estrito, já que a protagonista não tem nome, ou seja, a autora não usou seu nome próprio, este é um dos romances mais ousados na atual safra de escritoras brasileiras, tanto pelo nível de exposição de uma história pessoal parcialmente verdadeira, como pelas cenas de sexo, uma explosão de sensações muito bem exploradas e pela recuperação da herança judaica, aspectos pouco presentes na moderna literatura brasileira.

\section{Referências}

AUGÉ, Marc. Non-lieux. Introduction à une anthropologie de la surmodernité. Paris: Seuil, 1992.

DERRIDA, Jacques. Mal de arquivo. Uma impressão freudiana. Tradução Cláudia de Moraes Rego. Rio de Janeiro: Relume Dumará, 2001.

FUKS, Betty B. Freud e a judeidade. A vocação do exílio. Rio de Janeiro: Jorge Zahar, 2000 .

HAREL, Simon. Les passages obligés de l'écriture migrante. Montréal: XYZ, 2005.

. Résistances du lieu et empiétements du virtuel. Les cybermnésies de Régine Robin. In: MORENCY, Jean, TOONDER, Jeanette den, LINTVELT, Jaap. Romans de la route et voyages identitaires. Montréal: Nota Bene, 2006. p. 299-324. 


\section{Conexão Letras}

LAFERRIÈRE, Dany. J'écris comme je vis. Entretien avec Bernard Magnier. Montréal : Lanctôt, 2000.

LEVY, Tatiana Salem. A chave da casa. Rio de Janeiro: Record, 2009.

MEMMI, Albert. Portrait d'un Juif. Paris: Gallimard, 1962.

PEREC, Georges. L'infra-ordinaire. Paris: Seuil, 1989.

ROBIN, Régine. Le Golem de l'écriture. De l'autofiction au Cybersoi. Montréal:

XYZ, 1997.

. L'immense fatigue des pierres. Biofictions. Montréal:XYZ, 1996. . http://www.er.uqam.ca/nobel/r24136 Acessado em 22 de maio de 2007.

VALERY, Paul. Stendhal. In: Oeuvres, Pléiade, t. 1, Paris:Gallimard, 1957.

VILAIN, Philippe. Défense de Narcisse. Paris:Grasset, 2005. 